\title{
Socio-Economic Impact of Root and Tuber Expansion Programme on Rural Farmers in Plateau State
}

\author{
${ }^{1}$ Dr. Okeh, B. I., ${ }^{2}$ Prof Atala, T. K., ${ }^{3}$ Prof B. Ahmed, ${ }^{4}$ Prof D. O. Omokore \\ ${ }^{\prime}$ (Reader), B.Sc. M. Ed, PhD (Agric. Extension and Rural Sociology) \\ ${ }^{2}$ B.Sc. M.Sc. PhD (Agric. Extension and Rural Sociology) \\ ${ }^{3}$ B.Sc. M.Sc. PhD (Agric. Economics) \\ ${ }^{4}$ B.SC. M.Sc. PhD (Agric. Extension and Rural Sociology) \\ ${ }^{I}$ Department Of Vocational And Technical Education Abu Zaria \\ ${ }^{2,3,4}$ Department Of Agric Economics And Rural Sociology Faculty Of Agriculture Abu Zaria
}

\begin{abstract}
Many agricultural programmes have been formulated and implemented aimed at improving the socio-economic status of the rural farmers through adoption of improved technology regarding production, processing and marketing strategies. Root and Tuber Expansion Programme(RTEP), one of such programmes became loan effective on $31^{\text {st }}$ July 2001. The study is aimed at comparing the socio-economic status of the Programme Participant Farmers and Non-programme Participant Farmers before and after RTEP. The sample size of 204 rural farmers made up of 102 PPFs and 102 NPPFs were the respondents, Proportionate random sampling and purposive sampling technique were used in selecting 102 PPFs and 102 NPPFs respectively. Data were collected with a set of validated questionnaire administered to the respondents 204 rural farmers. Descriptive statistics (mean, grand mean, standard deviation and frequency distribution) and inferential statistics (t-test and Omega squared) were used in the analysis of data. It was found that there are significant differences in the socio-economic variables compared between PPFs and NPPFs and even among PPFs after RTEP. However, the impact was not adequate, therefore RTEP should be enriched to be attractive to involve greater number of rural farmers so as to achieve greater number of rural farmers so as to achieve greater socioeconomic impact on the rural farmers in RTEP area of operation
\end{abstract}

Keywords: Socio-economic, Impact, Rural farmers

\section{Introduction}

Agriculture is crucial to the social and economic development of Nigeria. Nigeria agriculture is second only to petroleum as an important contributor to the Gross

Domestic Product (GDP) accounting for an estimated 31\% of GDP in 1998/99 and 51\% - 61\% in 1999/2000 (Njoku 2000). However Nigeria agriculture has been on a decline when compared with other sectors of the economy; agricultural production has been growing slowly and not stable as it has been fluctuating from $79 \%-81 \%$ between 2000 to 2002 and $85.6 \%$ to $86.7 \%$ between $2003-2005$ (Nworgu, 2005)

Within the last three decades, serious efforts have been made to make Nigeria economy self sufficient in food production. The efforts include the establishment of the State wide Agricultural Development Programmes (ADPs), National Accelerated Food Production Programme (NAFPP), Green Revolution, Operation Feed the Nation, National Fadama Programme, Food Security, Cassava Multiplication Programme (CMP) and Root and Tuber Expansion Programme (RTEP). The broad objectives of these programmes are to increase food production, enhance rural food security, income and livelihood of the farmer through improved crop production, processing and marketing.

Following the successful completion of Cassava Multiplication Programme (CMP), which made Nigeria the largest cassava producer in the world, the Root and Tuber Expansion Programme (RTEP) was formulated by the Food Agricultural Organisation (FAO) Investment Centre Board in 1995, negotiated by the International Fund for Agricultural Development (IFAD) Executive Board in 1999. The programme was launched in December 2000 and declared loan effective on $31^{\text {st }}$ July 2001. The overall objective of RTEP was to achieve a sustainable increase in production of cassava, yam cocoyam and potatoes, as well as their end product, thus enhance National food self-sufficiency and improve rural household food security, income and living condition of the rural farmers.

Root and Tuber Expansion Programme areas include 26 States and the Federal Capital Territory (FCT) Abuja. Plateau State is one of the States in the North East States of Nigeria. The programme is implemented by the Federal Ministry of Agriculture and rural development through the Federal Department of Agriculture. The key agencies in the implementation are the 26 ADPs and seven Federal Government agencies namely; Nigeria Stores and Produce Research Institutes (NSPRI), National Root Crop Research Institutes (NRCRI), National Food Research Agency (NFRA), National Root Crop Centre (NRCC), National Centre for Agricultural 
Mechanization (NCAM) and Cassava Enterprises Development Project (CEDP). The components of Root and Tuber Expansion Programme include the following

- Development of root and tuber crop technologies

- Multiplication and distribution of improved planting materials.

- Diversification of processing options, programme management and evaluation.

In Plateau State, there was Cassava Multiplication Programme (CMP) before the advent of RTEP. CMP contributed to increased cassava production. With the establishment of RTEP in Plateau State in 2001, efforts were made to include other root crops (yam, cocoyam, potatoes) in addition to cassava. The activities of the RTEP in Plateau State include; multiplication and distribution of improved root and tuber planting materials and adding value to root and tuber crops by processing, marketing and linking fabricators with processors. (ADPs, 2004). Since the Root and Tuber Expansion Programme was still ongoing, it will be appropriate to conduct an ex-post impact evaluation on the rural farmers. Therefore the study was directed at evaluating the socioeconomic impact of the first phase of RTEP on farmers in Plateau State.

According to Bonnet (1991) any programme planned without the involvement of the target beneficiaries is always faced with the problem of evaluation, and Root and Tuber Expansion Programme is not an exception. The major challenges confronting agricultural extension programmes in any society is that of evaluating the result of it planned programming efforts in influencing desired socio-economic changes. Williams (1998) observed that the only kind of evaluation peculiar to many publicly supported agricultural programme is the progress report published monthly, quarterly or annually based solely on the hunches of the reporting officer. This seems not enough to justify the effect of the programme on the Programme Participant and Nonprogramme Participant Farmers. Therefore there is urgent need to carry out an evaluation of the socio-economic impact of the RTEP on the rural farmers in Plateau state.

\section{Research Questions}

What are the socio-economic status of the programme participant farmers and non-programme participant farmers before and after RTEP.

\section{Objective Of The Study}

The overall objective of the study is to evaluate the socio-economic impact of RTEP on the farmers in Plateau State. Specifically, the study intends to compare the socio-economic status of the Programme Participant Farmers and Non-programme Participant Farmers in the study area before and after RTEP.

\section{Hypothesis}

There is no significant difference in the socio-economic status of the Programme Participant Famers and Non-programme Participant Farmers in the study area.

The impact of a project relates to changes in the production and actual living condition among project beneficiaries following from and attributable to the project (UNO, 1984). Impact is a special form of evaluation that deals with the effect of intervention programme output on the target beneficiaries. Horton (1999) defines impact as the broad long term economic, social and environmental effects resulting from the programme. Furthermore, to measure the impact of a project on target beneficiaries, the socio-economic conditions of the beneficiaries before and after the intervention of the programme should be compared, this will help one determine the level of achievement of the programme. Impact of agricultural programme may be measured in terms of changes in crop yield, food production, farm size, income realised, living condition, possession of household equipment, health and nutritional status and adoption of the improved technologies, which are socioeconomic variables. (Ajayi, 1996).

The impact studies or the socio-economic status of the farmers by the following (Agwunobi, 1993, Asiabaka, 1991, Olaiyide and Ogunfiditimi 1980, Obiechine and Otti 1985, Brian 1980, Fadoyemi (1999), Heyer 1971 Ajayi 1996, and Agbanu and Falousoro showed that annual income of the participant farmers increased, hectare of land with increased yield; socio-economic progress of the target beneficiaries, on effective use of farm machines and storage of farm produce, increase rice yield, farm income and adoption of improved technologies, improved living and satisfaction with agriculture as occupation, provision of physical infrastructures and better payment of children school fees. The studies revealed that the constraints to effective implementation of the programme included; lack of adequate storage facilities, poor farm in put supply, land tenure, inadequate credit facilities, poor contact with extension agent, complexity of the innovation and level of education.

\section{Study Area.}

\section{Methodology}


Plateau State is within the North Central States of Nigeria. It is located in the Guinea Savannah of Nigeria. It lies between longitude $7^{\circ} 3^{\prime}$ and $80^{\circ} 37^{\prime}$ East and between latitude $80^{\circ} 30^{\prime}$ and $10^{\circ} 30^{\prime}$ North with cultivable land mass of $35,000 \mathrm{kmsq}$. More than $80 \%$ of the population are farmers Plateau State has three agricultural zones namely Central, Northern and Southern. The Local Government areas involved in the study include Mangu, Bokkos, Langtan, Shandam and Riyom. The adequate rainfall and average relative humidity make Plateau State very conducive for root and tuber crop cultivation and livestock production too.

Five out of the eleven RTEP participating Local Government Areas were purposively selected for the study. Population of the study was made up of 1020 registered farmers involved in the RTEP and the rest farmers not involved in RTEP. 1020 PPFs formed the sample frame, proportional random sampling using $10 \%$ of participant farmers in each of the five LGAs was used in selecting 102 PPFs that formed the sample size of PPFs. Purposive sampling selection by chance of equal numbers of PPFs from each of the 5 LGAs was used in selecting 102 NPPFs that formed the sample size of NPPFs (see table 1)

Table 1 Sample Size for the Study.

\begin{tabular}{|c|c|c|c|c|c|}
\hline \multirow[t]{2}{*}{ Agricultural Zone } & \multirow[t]{2}{*}{ LGA } & \multicolumn{2}{|c|}{$\begin{array}{l}\text { Programme } \\
\text { (PPFS ) }\end{array}$} & $\begin{array}{c}\text { Non-Programme } \\
\text { Participant Farmers } \\
\text { (NPPFS) }\end{array}$ & \multirow[t]{2}{*}{$\begin{array}{l}\text { Tota } \\
1\end{array}$} \\
\hline & & Population (P) & $\begin{array}{l}\text { Sample } \\
10 \%\end{array}$ & $\begin{array}{l}\text { Sample (S) } \\
10 \%\end{array}$ & \\
\hline \multirow[t]{2}{*}{ Central Zone } & Mangu & 200 & 20 & 20 & 40 \\
\hline & Bokkos & 220 & 22 & 22 & 44 \\
\hline \multirow[t]{2}{*}{ Southern Zone } & Shendam & 200 & 20 & 20 & 40 \\
\hline & Langtang & 200 & 20 & 20 & 40 \\
\hline Northern Zone & Ryom & 200 & 20 & 20 & 40 \\
\hline Total & 5 LGAs & 1020 & 102 & 102 & 204 \\
\hline
\end{tabular}

Data collected with the use of structured validated questionnaire by the researcher with the help of ten trained enumerators were analyzed using descriptive statistics - (mean, grand mean) to determining the levels of adoption of RTEP technologies while t-test and Omega squared were used to determine the impact of RTEP on the socio-economic status of the PPFs and NPPFS in the study area.

\section{Data Analysis Technique}

Descriptive statistics and inferential statistics (t-test and Omega square)

$\mathrm{t}$ - was calculated by using the following formula.

$$
\mathrm{t}=\frac{\mathrm{m}_{1}-\mathrm{m}_{2}}{\frac{\sqrt{\left(\mathrm{sd}_{1}\right)^{2}}}{\mathrm{n}_{1}}+\frac{\sqrt{\left(\mathrm{sd}_{2}\right)^{2}}}{\mathrm{n}_{2}}}
$$

where $\mathrm{t}=\mathrm{t}$-ratio

$\mathrm{m}_{1}=$ mean of PPFs

$\mathrm{m}_{2}=$ mean of NPPFs

$\mathrm{sd}_{1}=$ mean deviation of PPFs

$\mathrm{sd}_{2}=$ mean deviation of NPPFs

$\mathrm{n}_{1}=$ number of PPFs

$\mathrm{n}_{2}=$ number of NPPFs

Omega squared $(\Omega)^{2}=\frac{t^{2}-1}{t^{2}+n_{1}+n_{2}-1}$

Where $\mathrm{t}=$ mean $\mathrm{t}$ - score (t-ratio)

$\mathrm{n}_{1}=$ Number of PPFs

$\mathrm{n}_{2}=$ number of NPPFs

The theoretical perspective which guides this study is the classical adoption-diffusion theory. The classical adoption diffusion theory is made up of two components namely; diffusion process and adoption process or innovation decision process. According to Roger (1983), the four element of diffusion process are the innovation which is an ideal practice or product that is perceived new by the potential user, communication through various channels over period of time in stages and among members of a social system. Thus the process involves the transmission of information about an innovation from an original source though the change agent to potential adopter, institutional environment and technologies attributes. The adoptation-diffusion perceptive was the theoretical framework used as the innovation examined was the RTEP technologies, the communication system was RTEP staff and the potential adopters were the rural farmers in Plateau State.

In developing the model for this study, an attempt was made to integrate the theories and findings of various experts. Obasi and Oguche (1995), Ajayi (1996), Walter (1999). Impact is the outcome of an input on the target population and it reflects a change in the living conditions among the programme beneficiaries following from and attributable to the programme (UNO, 1984). Mbawonku (1986) opined that input provided 
in any extension programme/project bring abstract change mainly; increase in the income of the beneficiaries, better standard of living, literacy and attitude which constitute output resulting from the inputs of the programme measured as impact. The impact of any agricultural extension programme is considered as the improvement in food production, farm income and employment in the programme area through effective technology and practice. (Obiechina and Oti, 1985). Hence any evaluation of an agricultural extension programme should answer the fundamental question whether the socio-economic conditions including standard of living of the target group have significantly changed as a result of the project activities.

Mbawonkwu 1986 in Ajayi (1996) stressed that the impact of an agricultural extension programme on the socio-economic activities of the entire farm families in the project area would be evaluated using the following indicators; Project Input (PI) Project Output (PO) Project Effect (PE) Project Impact (PIm) and Project beneficiaries (PB). The impact of the project on the beneficiaries is a function of the degree of the participation of the beneficiaries in the designing and implementation of the project. To measure the impact of the project beneficiaries, the socio-economic condition of the beneficiaries before and after the inception of the programme/project should be compared.

Ogunbameru (1986) opined that a more simplified and complete approach to studying the effectiveness of agricultural extension programme is the Reflective Evidence to Appraise Programme (REAP). This is a package mix for harvesting information on the effectiveness of extension work. It relies on the reflective evidence of project research. Reflective Evidence means that the project participants estimate or reflect upon the amount of change and pay-off brought about through the project. It is adaptable to a wide variety of agricultural extension programme as it focuses on how much participants have learned or gained from their participation and how much positive or negative pay-off experienced from applying what they have learnt or gained. A combination of project input, output, effect, impact, participant and non-participant, before and after model were used to generate a framework in addition to REAP and survey model. The frame work assumed that before the intervention of RTEP in Plateau State, a baseline survey to discover the needs and aspiration of the rural farmers were carried out, the result led to the development of achievable objectives by the RTEP management unit. The study went ahead to find out the impact of the achieved objectives have on the socio-economic status of the farmers. The intervention stage started with project inputs (RTEP Technologies) which generated project output made available to the participant farmers. Effective use of the project output by the participant farmers generated project effects. The adoption of the project output over time generated socio-economic impact on the farmers. Therefore, to access the socio-economic impact of RTEP on the rural farmers both independent and dependent socio-economic variables of the PPFs and NPPFs were compared. Data for the comparism were harvested using REAP and Survey Model. While REAP involved the collection of data from the farmers based on what they believed to be the impact of the RTEP, the Survey Model was used to collect data from PPFs and NPPFs on the basis of their perception or opinion about the activities and outcome of RTEP before and after.

\section{Result And Discussion}

In this study, the socio-economic impact of RTEP was evaluated by studying the changes in educational level, knowledge of improved innovations, possession of household equipment, health facilities, nutritional status, income, crop yield, farm and processing equipment, payment of children school fees, marketing strategy, utilization of produce, attitude to farming as a profession and membership of formal organisation.

Table 2 t-test analysis for differences in socio-economic status of NPPFs and PPFs

\begin{tabular}{|c|c|c|c|c|c|c|c|}
\hline $\begin{array}{llll}\text { Socioeconomic } & \text { variables } & \text { compared } & \text { for } \\
\text { NPPFs and PPFs } & & & \\
\end{array}$ & Group & Mean & $\begin{array}{l}\text { Std. } \\
\text { deviation }\end{array}$ & $\begin{array}{l}\text { Std. error } \\
\text { mean }\end{array}$ & $\mathrm{t}$ & Df & sig \\
\hline \multirow[t]{2}{*}{ Level of education } & Participant & 1.76 & 1.026 & .120 & 3.662 & 201 & .000 \\
\hline & Non-Participant & 1.27 & .904 & .090 & & & \\
\hline \multirow[t]{2}{*}{ Payment of children school fees } & Participant & 2.37 & .730 & .072 & 4.536 & 201 & .000 \\
\hline & Non-participant & 1.85 & .899 & .089 & & & \\
\hline \multirow{2}{*}{$\begin{array}{l}\text { Participation in agricultural development } \\
\text { activities }\end{array}$} & Participant & 2.26 & .688 & .068 & 2.792 & 201 & .000 \\
\hline & Non-participant & 1.94 & .947 & .094 & & & \\
\hline \multirow[t]{2}{*}{ Possession of household equipments } & Participant & 2.15 & .763 & .076 & 1.817 & 201 & .000 \\
\hline & Non-participant & 1.92 & .997 & .099 & & & \\
\hline \multirow[t]{2}{*}{ Nutritional status } & Participant & 2.38 & .646 & .064 & 9.636 & 201 & .000 \\
\hline & Non-participant & 1.42 & .778 & .077 & & & \\
\hline \multirow[t]{2}{*}{ Knowledge of improved innovation } & Participant & 2.26 & .703 & .070 & 10.600 & 201 & .000 \\
\hline & Non-participant & 1.23 & .691 & .069 & & & \\
\hline \multirow[t]{2}{*}{ Standard of living } & Participant & 2.23 & .595 & .059 & 6.905 & 201 & .000 \\
\hline & Non-participant & 1.50 & .867 & .086 & & & \\
\hline \multirow[t]{2}{*}{ Attitude towards farming as a profession } & Participant & 2.63 & .525 & .052 & 8.132 & 201 & .000 \\
\hline & Non-participant & 1.89 & .747 & .074 & & & \\
\hline \multirow[t]{2}{*}{ Crop yield } & Participant & 2.46 & .557 & .055 & 7.372 & 201 & .000 \\
\hline & Non-participant & 1.75 & .793 & .079 & & & \\
\hline Marketing strategy & Participant & 2.07 & 679 & .067 & 4.532 & 201 & .000 \\
\hline
\end{tabular}




\begin{tabular}{|c|c|c|c|c|c|c|c|}
\hline & Non-participant & 1.63 & .689 & .069 & & & \\
\hline \multirow[t]{2}{*}{ Level of income } & Participant & 2.46 & .665 & .065 & 7.121 & 201 & .000 \\
\hline & Non-participant & 1.82 & .623 & .062 & & & \\
\hline Health facilities & Participant & 1.69 & .731 & .072 & 4.130 & 201 & .000 \\
\hline \multirow[t]{2}{*}{ Utilization of the produce } & Participant & 2.38 & .690 & .068 & 7.074 & 201 & .000 \\
\hline & Non-participant & 1.64 & .795 & .079 & & & \\
\hline Membership of formal organisation & Participant & 2.12 & .915 & .091 & 5.719 & 201 & .000 \\
\hline \multirow[t]{2}{*}{ Farm equipment in possession } & Participant & 1.81 & .864 & .086 & 4.911 & 201 & .000 \\
\hline & Non-participant & 1.23 & .835 & .083 & & & \\
\hline \multirow[t]{2}{*}{ Modern farm implements } & Participant & 1.03 & .724 & .072 & 1.685 & 201 & .000 \\
\hline & Non-participant & .85 & .780 & 0.78 & & & \\
\hline \multirow[t]{2}{*}{ Fabricated modern processing equipments } & Participant & .87 & .840 & .083 & 2.503 & 201 & .000 \\
\hline & Non-participant & .60 & .679 & .068 & & & \\
\hline
\end{tabular}

Table 2 shows that the socio-economic variables of the PPFs and NPPFs

after RTEP activities showed high difference in: attitude to farming as a profession PPFs 2.63, NPPFs 1.89, crop yield PPFs 2.46 NPPFs 1.75, payment of children school fees PPFs 2.37 NPPFs 1.85, knowledge of improved innovation PPFs 2.26 NPPFs 1.23, standard of living PPFs 2.23 NPPFs 1.50, level of income PPFs 2.46 NPPFs 1.82, utilization of produce PPFs 2.38 NPPFs 1.64, possession of household equipment 2.15 NPPFs 1.92, nutritional status PPFs 2.38 NPPFs 1.42, health care facilities PPFs 1.69 NPPFs 1.23. The difference was low in possession of modern processing farm equipment in possession.

The study also revealed that the socio-economic status of PPFs significantly improved after RTEP see Table 3.

Table 3 Socio-economic variables compared among PPFs before and after RTEP

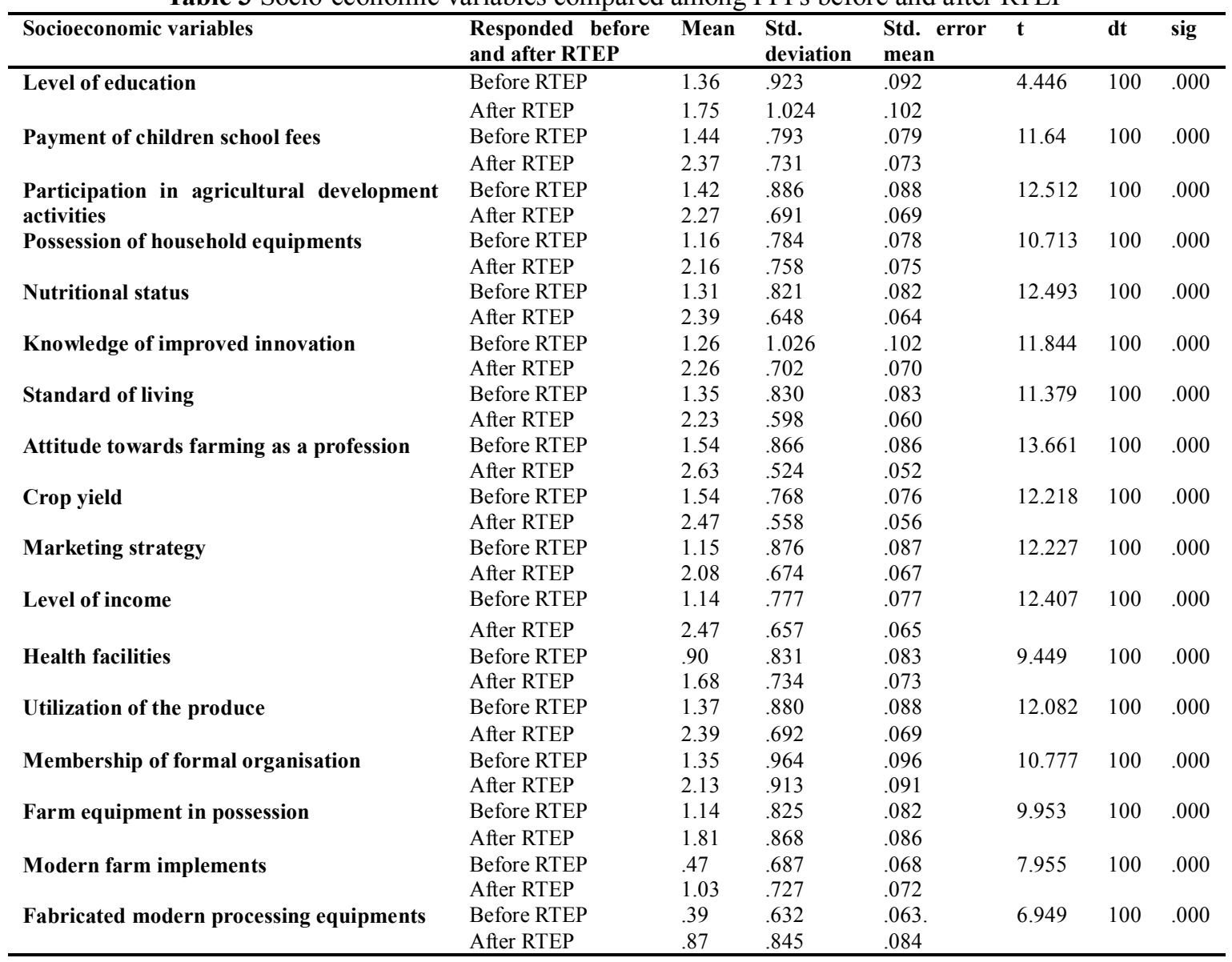

This suggests that RTEP was successful in the impact on the level of income, crop yield, attitude to farming as an occupation, payment of children school fees, health care facilities, utilization of produce, standard of living nutritional status, possession of household equipment, marketing strategy and level of education. This impact on socio-economic status agreed with the studies of Agwunobi 1993, Fadoyemi, Horton (1993), Ajaiyi 1996, Ugbomeh 1984, Aribisala (1983), Olayide and Ogunfiditimi 1980, Obiechina and Oti 1985, Brain 1980. 
The impact of any agricultural programme should be seen in terms of economic, social and environmental effect resulting from the programme, (Horton 1993). Ajaiyi 1996 opined that the impact of any programme on the socio-economic variables should be determined by studying pre and post intervention programme. To measure this, the socio-economic condition of the target beneficiaries before and after the intervention should be compared as it will help one determine the level of achievement of the programme. Furthermore, he concluded that the impact of any agricultural programme may be measured in terms of changes in crop yield, food production, income, farm size, living condition, health status and nutritional status which are socioeconomic variables.

\section{Hypothesis}

There is no significant difference in the socio-economic status of the programme participant farmers and Non-programme participant farmers in the study area.

To test the hypothesis, mean scores of socio-economic status of PPFs and NPPFs, standard deviation and standard error of the mean after RTEP were computed. Based on these scores, t-score was computed for difference between the two groups see Table 2. Table 2 shows significant difference at 0.05 level and above in all the socio-economic impact of RTEP in all the variables except in the possession of farm and processing equipment.

As the t-score varied widely from variable to variable it became necessary to compute the grand mean score and the respective t-score. See Table 4.

Table 4 t-test analysis for differences between NPPFs and PPFs in their socio-economic status

\begin{tabular}{llllllllll}
\hline Variables & Respondents & Mean & SD & $\begin{array}{l}\text { Std. } \\
\text { mean }\end{array}$ & error & T & df & Sign (2) & Omega sq. \\
\hline $\begin{array}{l}\text { Socio-economic } \\
\text { impact }\end{array}$ & PPFs N=102 & 2.0547 & 0.7254 & 0.07188 & 5.4781 & 201 & 0.01076 & 0.1245 \\
& NPPFs N = 102 & 1.4828 & 0.7985 & 0.0794 & & & & \\
\hline
\end{tabular}

Table 4 shows significant difference between PPFs and NPPFs in the socio-economic impact of RTEP. Omega squared was used to find out from the significant scores how much variance in the dependent variables (socio-economic impact) is explained by the difference between the PPFs and NPPFs.

$(\Omega)^{2}=\frac{5.48^{2}-1}{5.48^{2}+203}=\frac{29.0098}{333.0095}$ $=0.1245$

Although the difference between PPFs and NPPFs in the socio-economic impact of RTEP was significant, that difference could explain only $12 \%$ of the variance. The result of the study did not support the hypothesis that states: there is no significant difference between the socio-economic status of the PPFs and NPPFs.

Since only $12 \%$ of the variance could be explained, it become necessary that the socio-economic impact before and after RTEP among PPFs be computed.

Table 5 t-test analysis on PPFs on their socio-economic impact before and after RTEP

\begin{tabular}{llllllllll}
\hline Variables & Respondents & Mean & SD & $\begin{array}{l}\text { Std. } \\
\text { mean }\end{array}$ & error & $\mathrm{t}$ & $\mathrm{df}$ & Sign (2) & Omega sq. \\
\hline Socio-economic impact & Before & 1.21 & 0.82 & 0.08 & & 6.344 & 100 & 0.000 & 0.2779 \\
& After & 2.05 & 1.04 & 0.068 & & & & & \\
& & & & & & & &
\end{tabular}

The result in table 5 revealed high significant differences between before and after RTEP in the socioeconomic impact among PPFs (6.34). Omega squared was computed to find out the strength of their differences before and after TEP.

$\Omega^{2}=\frac{6.34^{2}-1}{6.34^{2}+102-1}$

$=0.28$

Statistically, significant differences between the socio-economic impact before and after RTEP among PPFs explained only $28 \%$ of the variance. This result also failed to support the hypothesis too and should be interpreted with care because the difference could not explain $72 \%$ of the variance.

\section{Conclusion}


Root and tuber expansion programme made a significant impact on the socio-economic status of the Programme Participant farmers in the study area as their socio-economic status differed greatly from that of Non-programme participant farmers. Also there was significant difference among the PPFs in their socioeconomic status before and after RTEP. RTEP significantly succeeded in bringing positive changes in the socioeconomic status of the rural farmers in Plateau State especially the PPFs.

\section{Recommendations}

To enhance better socio-economic status of the rural farmers in Plateau State, more farmers should be encouraged to be beneficiaries of RTEP by enriching RTEP activities so as to attract more farmers.

\section{References}

[1]. Agwunobi, C.A. (1993) Impact of the Shell Petroleum Agric Extension Programme on the Participating Farmers in Imo State, An Unpublished M.Sc Thesis Department of Agricultural Extension, University of Nigeria Nsukka.

[2]. Ajayi, A.R. (1996) An Evaluation of the Socio-economic impact of the Ondo State Ekiti- Akoko Agricultural Development Project on the Rural Farmers. A Ph.D Dissertation, Department of Agricultural Extension, University of Nigeria Nsukka.

[3]. Aribisala, T.S.B, (1983) Nigeria's Green Revolution; Achievement, Problem and Prospects, Distinguished lecture Series NISER Ibadan Nigeria 1: 1-40

[4]. Asiabaka, C.C (1991) The role of Imo State ADP IN boosting Food production. The Nigerian Journal of Agricultural Extension 6. (1 \&2): 47.

[5]. Brain, C.D, (1980) Socio-economic Impact of the Funtua Agricultural Development project. Department of Agricultural Economics and Rural Sociology I.A.R ABU Zaria.

[6]. Fadayomi, T.O (1988), Rural development and Migration in Nigeria NISER Ibadan Nigeria.: 1 - 15

[7]. Heyer, J.D, and J Morris (1974) Rural Development in Kenya. East Africa Publishing house Nairobi.

[8]. Horton D, Ballantyne, P. Perterson, W, Urebe, B, Gapascin D. and K. Sherikda, (1993) Monitoring and Evaluating agricultural research: a Source book. Walling Ford: CABI and ISNAR

[9]. Obasi, N.I and N. Oguche (1995) Innovation Programmes in rural development in Nigeria. An evaluation of the better life programme using the APBS Framework in F.C. Eboh, C.U. Okoye and D. Ayichi (eds). Rural Development in Nigeria Concepts processes and prospects. Enugu Auto Century publishers $73-85$

[10]. Obiechina, C.O. and F. Otti (1985) Socio Economic Impact of Rice production Technology on Rural area of Anambra State. Nigeria Journal of Rural Development and Co-operation Studies 1(2):132 -146.

[11]. Ogunfiditimi,T.O (1980). Community Survey Methods, Statistical Technique and Computer Analysis. Mary Grant Educational Publishers

[12]. Ogunbameru, B.O (1986) Application of "REAP" Model Evaluating Extension Education programme Focus on Borno Farm Mechanization Training ]programme The Nigerian Journal of Agric. Extension. 4(1): 2-9.

[13]. Mbawonku, A.F. (1986). Economic Evaluation of the Anambra/Imo (ANIMO) Rice Project in Nigeria. Agricultural Administration and Extension Journal, 22(3): 149 - 160

[14]. Njoku, P.C. (2000). Nigerian Agriculture as the challenge of the $21^{\text {st }}$ Century. Journal of Tropical Agriculture, Food, Environmental Extension.

[15]. Nworgu, F.C. (2005). Prospects and Pitfalls of Agricultural Production in Nigeria. Ibadan, Nigerian Blessed Publications Consultants.

[16]. Olayide, S.O. (1980) Agricultural Technology and Nigerian Small Farmers. Problems and Prospect in Integrated Rural Development, S.O Olayide, J.A Eweka and Bellow Osagie (eds) University of Ibadan 51 -66.

[17]. Ugbomeh, G.M.M (1984) An Evaluation of YFC Scheme in Edo and Delta States, Nigeria Unpublished Ph.D Thesis Department of Agricultural Extension. University of Nigeria, Nsukka.

[18]. UNO, (1984) Admin Committee on Coordination Task Force on Rural Development Guiding Principles for the Design and use of Monitoring and Evaluation in Rural Development Project and programmes, Rome UNO.

[19]. Williams, S.K.T (1998) Rural Development in Nigeria. Obafemi Awolowo University Ile-Ife, Osun State, Nigeria : 1-124. 